Archive for

Organic Chemistry

Arkivoc 2020, part viii, $70-80$

\title{
Synthesis and heterocyclization of triterpenic 1,3-diketones
}

\author{
Mikhail A. Nazarov, Irina A. Tolmacheva, ${ }^{*}$ and Victoria V. Grishko \\ Perm Federal Scientific Center, Acad. Korolev St. 3, 614013 Perm, Russia \\ Email: tolmair@gmail.com
}

Received 08-28-2020

Accepted 11-15-2020

Published on line 11-29-2020

\section{Abstract}

Procedures for the synthesis of some new lupane and $18 \alpha \mathrm{H}$-oleanane pyrazole and isoxazole derivatives from betulin are reported. The synthetic scheme for the preparation of 1,2-azoles involves aldol condensation of triterpenic aldehydes with acetone as a key stage.

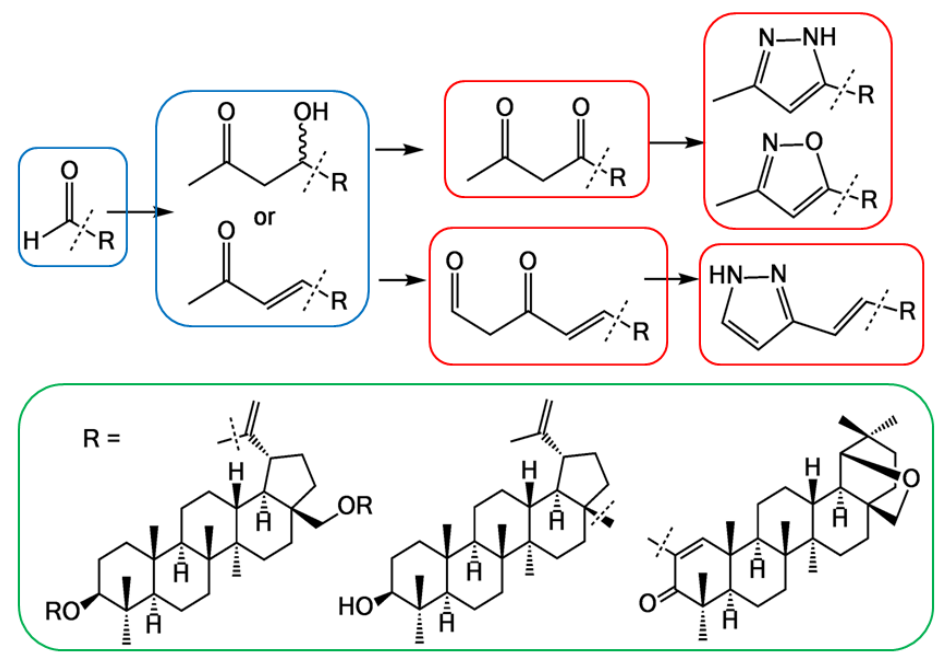

Keywords: Triterpenoids; aldehydes; aldol condensation; 1,3-diketones; pyrazoles; isoxazoles 


\section{Introduction}

The strategy for the design of hybrid molecules, including those from natural compounds, is based on the methods of modern organic and medicinal chemistry and provides the preparation of chemical entities with two (or more than two) structural domains with different biological functions ${ }^{1}$. In accord with the molecular hybridization concept, heterocyclic modification of triterpenic skeleton can provide new hybrid molecules with high biological potential and bioavailability ${ }^{2-5}$. Concurrently, $\beta$-dicarbonyl compounds have shown themselves as useful building blocks for the construction of heterocycles with one, two, or more heteroatoms ${ }^{6-8}$. So, 1,3diketones obtained from 3-oxo derivatives of allobetulin, betulinic, dihydrobetulonic, 23-hydroxybetulinic, oleanolic, maslinic, and glycyrrhetinic acids were successfully used as convenient and promising objects in the synthesis of $\mathrm{N}, \mathrm{O}$-based five-membered heterocycles, such as pyrazoles, oxazoles, and isoxazoles condensed with triterpenic skeleton at the 2,3-position ${ }^{9-19}$. Herein, we describe a convenient synthetic route for the preparation of lupane and oleanane 1,3-diketones with use of the aldol condensation. Further heterocyclization of the synthesized triterpenic 1,3-diketones to derivatives with a 1,2-azole fragment (pyrazole and isoxazole) in A or E cycles of triterpenoid has also been evinced as possible.

\section{Results and Discussion}

Betulin 1 and its derivatives - 3,28-betulin dibenzoate 2, 3,28-betulin diacetate 3, allobetulone 4, and betulinal 5 - were used as easily available starting compounds for the synthesis of new triterpenic 1,3-diketone derivatives. First, via $\alpha, \beta$-unsaturated aldehyde intermediates $6,7,9^{20-23}$, compounds $\mathbf{2 - 4}$ were converted to $\beta$ hydroxyketones 10-12 according to the antecedently described method ${ }^{20,23}$ (Scheme 1).

The aldol reaction of compounds 10-12 with acetone was discontinued at first signs of the formation (TLC) of a croton's by-product produced by the water elimination of their $\beta$-hydroxy ketone fragment. In turn, the aldol condensation of betulinal $\mathbf{5}$ with acetone carried out at room temperature and using $t$-BuOK- $t$-BuOH led to the formation of a new $\alpha, \beta$-unsaturated methyl ketone $\mathbf{1 3}$ as a single product in an excellent $80 \%$ yield. The ${ }^{1} \mathrm{H}$ NMR spectrum of $\alpha, \beta$-unsaturated methyl ketone 13 showed $\mathrm{CH}_{3}-33$ protons of the methyl ketone moiety recorded as a singlet at $2.27 \mathrm{ppm}$. The $E$-configuration of the $\mathrm{C}-28-\mathrm{C}-31$ double bond was confirmed by a large coupling constant $(16.5 \mathrm{~Hz})$ between two olefinic protons at 6.16 and $7.07 \mathrm{ppm}$. The signals of C-28, C-31 carbon atoms and carbonyl group were observed in ${ }^{13} \mathrm{C}$ NMR spectrum of compound 13 at 130.19, 149.62 and 198.58 ppm, respectively.

The different location of aldehyde group in the structure of compounds 5-9 enabled the introduction of a 1,3-diketone fragment at C-2, C-28 and C-30 positions of the triterpenic core. According to TLC, chromium (VI) oxide in anhydrous pyridine, normally used as an oxidation reagent, was not suitable for $\beta$-hydroxy ketones 10 and 11 because in both cases the reaction proceeded with the formation of a multicomponent hard-toseparate product mixture. Lupane 1,3-diketones 14,15 were obtained in $30 \%$ yields by treating compounds 10 and 11 with PCC in anhydrous $\mathrm{CH}_{2} \mathrm{Cl}_{2}$ or with the Jones reagent in acetone (Scheme 2). 18aH-Oleanane 1,3diketone 16 was obtained by oxidation of $\beta$-hydroxy ketone 12 with the Jones reagent (other oxidizing systems failed to lead to a good result). 

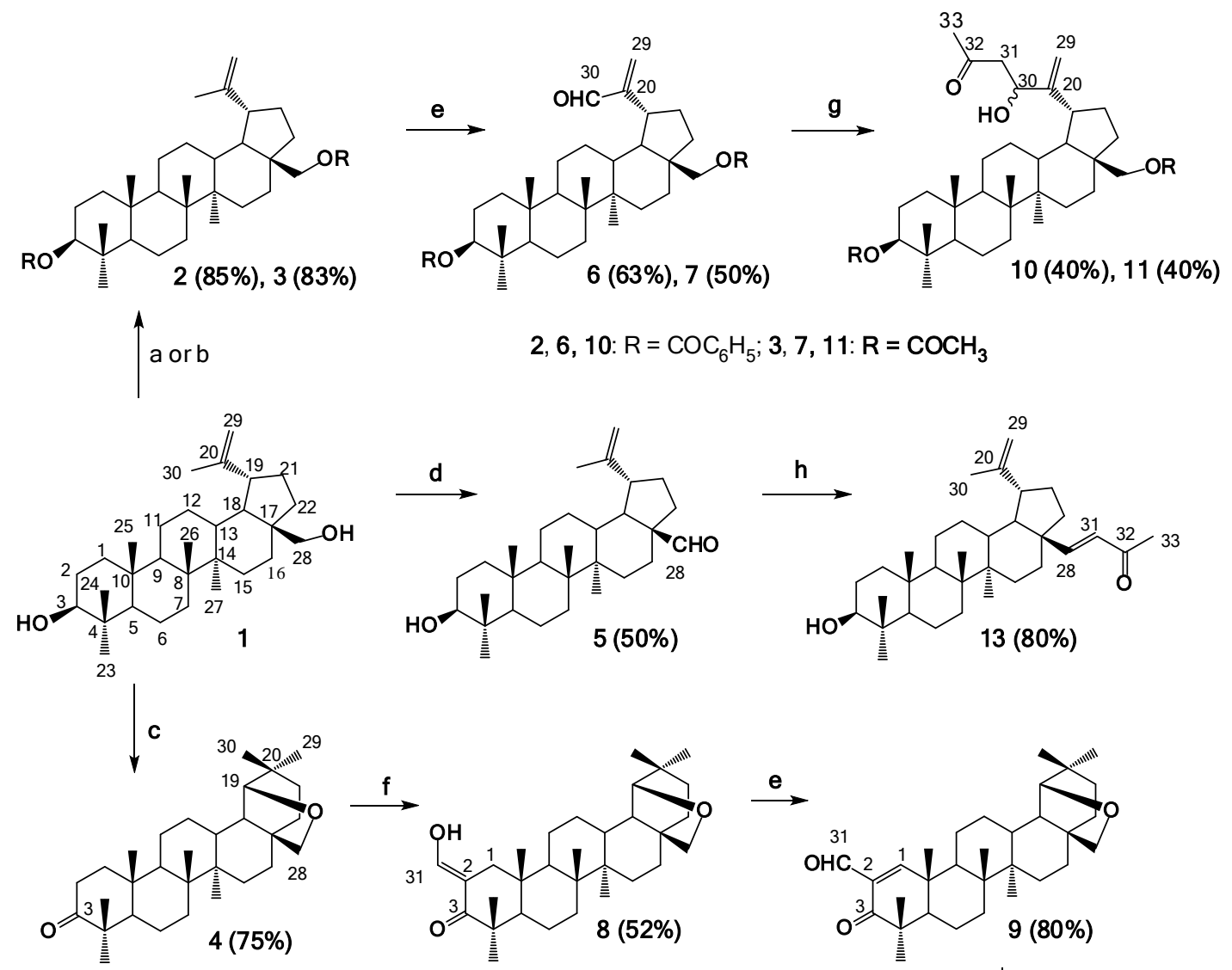

Reagents and conditions:

$a, \mathrm{C}_{6} \mathrm{H}_{5} \mathrm{COCl}$, DMAP, Py (for 2);

b. $\mathrm{CH}_{3} \mathrm{COCl}$, DMAP, Py (for 3 );

c, 1) $\mathrm{HCOOH}$; 2) $\mathrm{KOH}, \mathrm{EtOH}$; 3) $\mathrm{CrO}_{3}, \mathrm{H}_{2} \mathrm{SO}_{4}$, acetone;

d, $\mathrm{PCC}, \mathrm{CH}_{2} \mathrm{Cl}_{2}, \mathrm{rt}$;

$e, \mathrm{H}_{2} \mathrm{SeO}_{3}, 1,4$-dioxane, reflux;

$f$, $\mathrm{HCOOC}_{2} \mathrm{H}_{5}, \mathrm{NaH}$, benzene, reflux:

g, $\left(\mathrm{CH}_{3}\right)_{2} \mathrm{CO}$-benzene 1:2, $10 \% \mathrm{NaOH}$, rt.

$h$, $\left(\mathrm{CH}_{3}\right)_{2} \mathrm{CO}, t-\mathrm{BuOH}, t$-BuOK, rt.

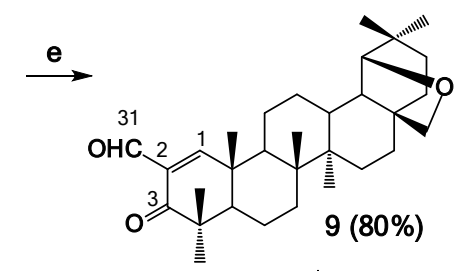

$\downarrow \mathbf{g}$

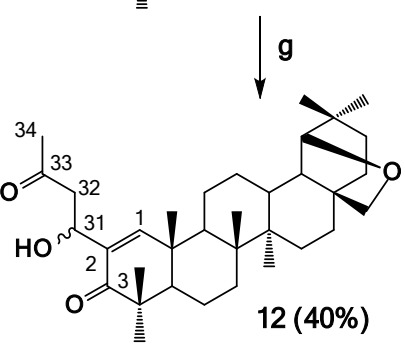

Scheme 1. Synthesis of triterpenic $\beta$-hydroxy ketones $\mathbf{1 0 - 1 2}$ and $\alpha, \beta$-unsaturated methyl ketone $\mathbf{1 3}$ from betulin 1 .

Lupane 1,3-diketones $\mathbf{1 4}$ and $\mathbf{1 5}$ are completely enolized at the C-30 atom; that was confirmed by the data of ${ }^{1} \mathrm{H}$ and ${ }^{13} \mathrm{C}$ NMR spectra with characteristic signals: (1) a singlet of protons $\mathrm{H}_{3}-33$ at 2.11-2.12 ppm and a signal of the carbon atom C-32 at 193.13-193.17 ppm were assigned to the methyl ketone fragment; (2) a singlet of enol hydroxyl in the downfield area at 15.65-15.67 ppm and a signal of proton $\mathrm{H}-31$ at 5.85-5.87 ppm were identified as an enol fragment. Two enol forms A and B for 18 $\alpha \mathrm{H}$-oleanane 1,3-diketone 16 in solution at the ratio 7:3 were registered on the basis of the integrated intensity of the signals of protons $\mathrm{H}_{3}-34$ (1.94 and $2.13 \mathrm{ppm}$ ) and proton $\mathrm{H}-19$ (3.53 and $3.54 \mathrm{ppm}$ ), as well as the proton of enolic hydroxyl (15.63 and $15.70 \mathrm{ppm}$ ) in the ${ }^{1} \mathrm{H}$ NMR spectrum. Lupane 1,3-diketone 17 was obtained by the Claisen condensation of $\alpha, \beta$-unsaturated methyl ketone $\mathbf{1 3}$ with $\mathrm{HCOOC}_{2} \mathrm{H}_{5}$ in $65 \%$ yield (Scheme 3 ). The enolization of the ketone group C-34 of compound $\mathbf{1 7}$ was confirmed by the registration of doublet signals of olefinic protons $\mathrm{H}-28$ and $\mathrm{H}-31$ (5.97 and $7.19 \mathrm{ppm}$ ) and protons $\mathrm{H}-33$ and $\mathrm{H}-34$ (5.57 and $8.46 \mathrm{ppm}$ ), a signal of carbonyl atom carbon C32 at $182.99 \mathrm{ppm}$, and a signal of $\mathrm{C}-34$ atom at $182.52 \mathrm{ppm}$ in the ${ }^{1} \mathrm{H}$ and ${ }^{13} \mathrm{C}$ NMR spectra. 


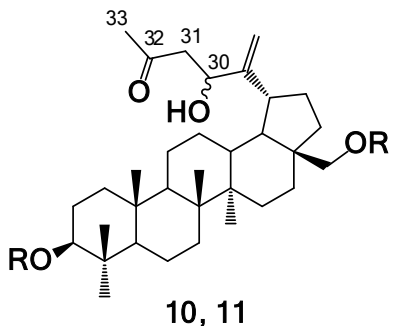

10,11

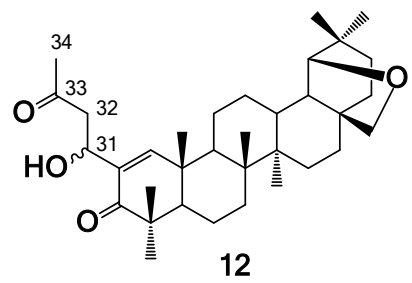

Reagents and conditions: a, $\mathrm{CrO}_{3}, \mathrm{H}_{2} \mathrm{SO}_{4},\left(\mathrm{CH}_{3}\right)_{2} \mathrm{CO}, \mathrm{AcONa}, \mathrm{rt}$; b, $\mathrm{PCC}, \mathrm{CH}_{2} \mathrm{Cl}_{2}$, $\mathrm{tt}$;
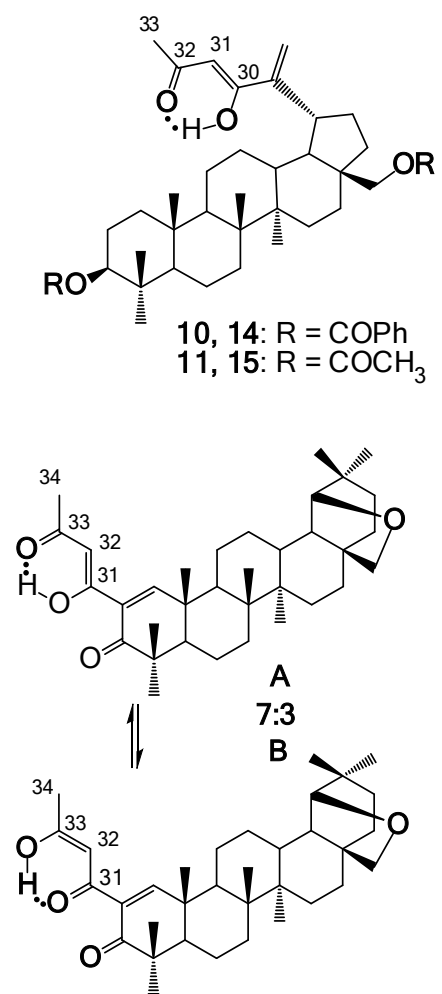

Scheme 2. Synthesis of triterpenic 1,3-diketones 14-16.

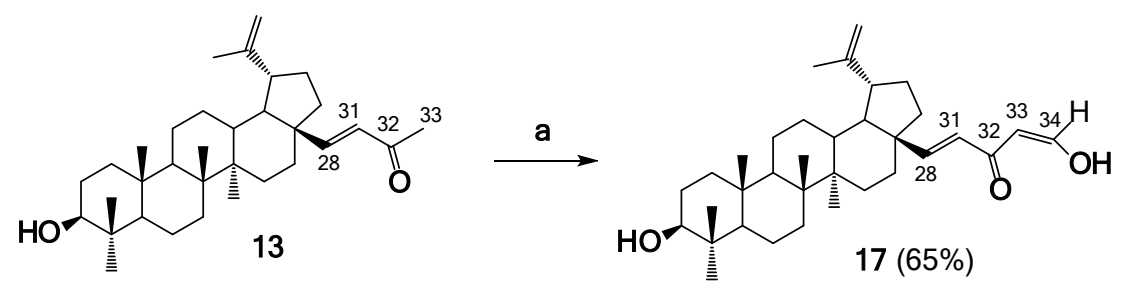

Reagents and conditions: $a, \mathrm{HCOOC}_{2} \mathrm{H}_{5}, t-\mathrm{BuOH}, t-\mathrm{BuOK}$, $\mathrm{t}$.

Scheme 3. Synthesis of triterpenic 1,3-diketone 17.

To obtain pyrazole derivatives, compounds 14, 16, 17 were heated with hydrazine hydrate in an alcohol-acetic acid mixture (1:1) for $1.5 \mathrm{~h}$ (Scheme 4).

The ${ }^{1} \mathrm{H}$ NMR spectra of compounds 18 and 19 showed the presence of two singlet signals at 2.28 and 6.12-6.23 ppm which conjointly with a broad signal at 8.20-8.22 ppm were assigned to protons $\mathrm{H}_{3}-6^{\prime}, \mathrm{H}-4^{\prime}$ and the proton of $\mathrm{NH}$ group of a substituted pyrazole cycle, respectively, whereas the ${ }^{13} \mathrm{H}$ NMR spectra revealed the characteristic signals of heterocyclic fragment at 102.02-102.62 and 141.25-147.12 ppm. In the ${ }^{1} \mathrm{H} N M R$ spectrum of compound 20, the signals of $\mathrm{H}-4$ ' and $\mathrm{H}-5^{\prime}$ protons of the pyrazole fragment were recorded as two doublets at 6.33 and $7.49 \mathrm{ppm}$ with a coupling constant of $1.7 \mathrm{~Hz}$ and the $\mathrm{NH}$ proton signal at $5.79 \mathrm{ppm}$. The treatment of triterpenic 1,3-diketones 14, 16 with hydroxylamine hydrochloride in aqueous EtOH in the presence of $\mathrm{CH}_{3} \mathrm{COONa}$ at reflux afforded isoxazole derivatives $\mathbf{2 1 , 2 2}$ in $86 \%$ and $73 \%$ yields, respectively (Scheme 5). In the ${ }^{1} \mathrm{H}$ NMR spectra of the compounds $\mathbf{2 1}$ and 22, the characteristic singlet signals of protons $\mathrm{H}_{3}-6^{\prime}$ and $\mathrm{H}-4{ }^{\prime}$ of isoxazole fragment were recorded at 2.30-2.31 and 6.12-6.61 ppm, respectively. 

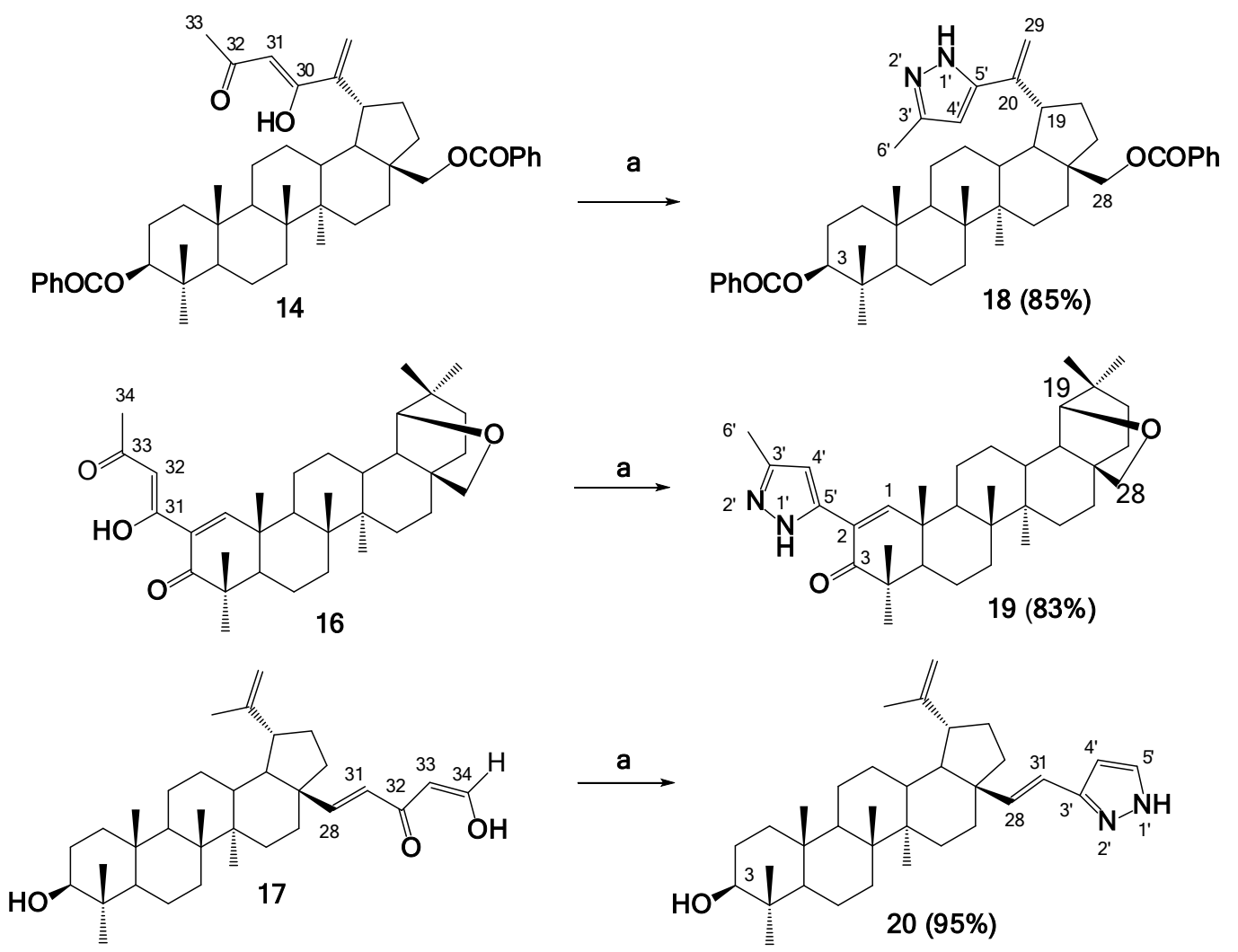

Reagents and conditions: $a, \mathrm{NH}_{2} \mathrm{NH}_{2}{ }^{*} \mathrm{H}_{2} \mathrm{O}, \mathrm{EtOH} ; \mathrm{AcOH}$, reflux.

Scheme 4. Synthesis of triterpenic pyrazoles 18-20.
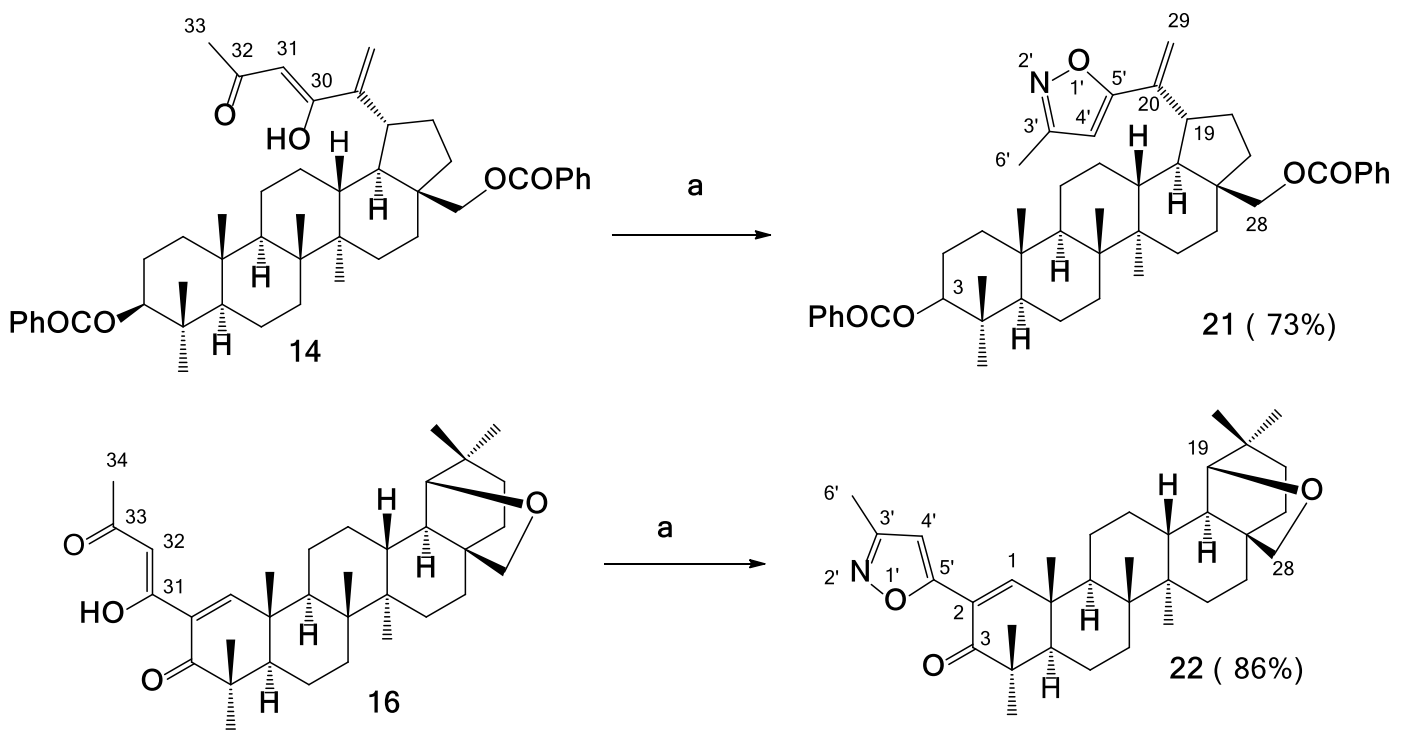

Reagents and conditions: $a, \mathrm{NH}_{2} \mathrm{OH}^{*} \mathrm{HCl}, \mathrm{EtOH}, \mathrm{AcONa}$, reflux.

Scheme 5. Synthesis of triterpenic isoxazoles 21, 22. 


\section{Conclusions}

Triterpenic derivatives with a pyrazole or isoxazole fragment in the A or E cycle of triterpenoids were synthesized from the lupane and 19ß,28-epoxy-18 $\alpha \mathrm{H}$-oleanane 1,3-diketones obtained from commercially available pentacyclic triterpenoid betulin. The synthetic route to triterpenic 1,2-azoles involved the reaction of aldol condensation of $\alpha, \beta$-unsaturated aldehydes with acetone, the products of which as $\beta$-hydroxyketone and methyl ketone were converted to 1,3-diketones, whose participation in reaction with hydrazine hydrate and hydroxylamine led to target heterocyclic derivatives.

\section{Experimental Section}

General. The ${ }^{1} \mathrm{H},{ }^{13} \mathrm{C}$ and $2 \mathrm{D}$ NMR spectra $(\mathrm{HMBC})(\delta, \mathrm{ppm} ; \mathrm{J}, \mathrm{Hz})$ were recorded for solutions in $\mathrm{CDCl}_{3}$ using a Bruker AVANCE II spectrometer $\left(400 \mathrm{MHz}\right.$ and $100 \mathrm{MHz}$, respectively), relative to HMDS. IR spectra $\left(\mathrm{v}, \mathrm{cm}^{-1}\right)$ were recorded on a Bruker 66/S IFS Fourier spectrometer using a thin film obtained by evaporation from the solution of the substance in $\mathrm{CHCl}_{3}$. Melting points were determined on an OptiMelt MPA100 device at the heating rate $1^{\circ} \mathrm{C} / \mathrm{min}$. Optical rotation was measured on a Perkin-Elmer 341 polarimeter using sodium $\mathrm{D}$ for $\mathrm{CHCl}_{3}$ solutions at $589 \mathrm{~nm}$. Elemental analysis was preformed using a vario $\mathrm{EL}$ cube elemental analyzer. Chromato-mass spectra were analyzed using Agilent Technologies 6890N, capillary column HP-5ms $15000 x$ $0.25 \mathrm{~mm}$, electronic ionization as sample ionization method. Thin layer chromatography (TLC) on "Sorbfil" plates was used to control the reaction course and substance purity by visualization under UV light (254 $\mathrm{nm}$ ). The samples were then subjected to treatment with a $5 \%$ solution of $\mathrm{H}_{2} \mathrm{SO}_{4}$ and heating at $95-100{ }^{\circ} \mathrm{C}$ for $2-3$ min. Column chromatography (CC) procedure was performed using Macherey-Nagel 60 Silica (0.063-0.2 mm) as an adsorbent. For each compound, eluents were selected individually. 3,28-Betulin dibenzoate 2 and 3,28betulin diacetate 3 synthesized by treating technical betulin with an acylating agent (benzoyl chloride or acetic anhydride) in pyridine ${ }^{21,24}$. Betulinal 5 was obtained by oxidation of the C28 hydroxyl group of betulin by PPC in pyridine ${ }^{25}$.

3ß-Hydroxy-28-(2-oxopropylidene)lup-20(29)-ene (13). $t$-BuOK (4 mmol) was added to a solution of aldehyde $5(2.3 \mathrm{mmol})$ in $t$ - $\mathrm{BuOH}(50 \mathrm{ml})$ and acetone $(2 \mathrm{ml})$. The reaction mixture was stirred for $2 \mathrm{~h}$ at $\mathrm{rt}$. With $10 \% \mathrm{HCl}$ added, the reaction mixture was extracted with ethyl acetate $(30 \mathrm{~mL} \times 2)$. The organic layer was separated, washed with $\mathrm{H}_{2} \mathrm{O}(5 \times 10 \mathrm{ml})$, and dried over anhydrous $\mathrm{MgSO}_{4}$. The solvent was evaporated, and the residue was subjected to $\mathrm{CC}$ (eluent: light petroleum-ethyl acetate, $10: 1$ ). Yield: $80 \%$, m.p. $191.6{ }^{\circ} \mathrm{C},[\alpha]_{D}^{21}-24.0(c 0.5$, $\left.\mathrm{CHCl}_{3}\right)$. IR $\left(\mathrm{cm}^{-1}\right): 3447,1672 .{ }^{1} \mathrm{H}$ NMR $\left(400 \mathrm{MHz}_{\mathrm{CDCl}}\right): \delta_{\mathrm{H}} 7.07$ and $6.16(2 \mathrm{H}, 2 \mathrm{~d}, J 16.5 \mathrm{~Hz}, 28-\mathrm{H}, 31-\mathrm{H}), 4.72$ and $4.60\left(2 \mathrm{H}, 2 \mathrm{~s}, 29-\mathrm{H}_{2}\right), 3.16(1 \mathrm{H}, \mathrm{dd}, J 5.1,11.2 \mathrm{~Hz}, 3-\mathrm{H}), 2.45(1 \mathrm{H}, \mathrm{td}, J$ 11.1, $5.3 \mathrm{~Hz}, 19-\mathrm{H}), 2.27\left(3 \mathrm{H}, \mathrm{s}, 33-\mathrm{H}_{3}\right)$, $1.68\left(3 \mathrm{H}, \mathrm{s}, 30-\mathrm{H}_{3}\right), 0.97,0.95,0.93,0.81,0.74\left(15 \mathrm{H}, 5 \mathrm{~s}, 5 \mathrm{CH}_{3}\right) .{ }^{13} \mathrm{C} \mathrm{NMR}\left(100 \mathrm{MHz} \mathrm{CDCl}_{3}\right): \delta_{\mathrm{C}} 198.58,152.72$, $149.62,130.19,110.06,78.93,55.33,50.38,50.06,49.70,47.85,42.79,40.82,38.99,38.84,38.76,38.72$, 37.17, 34.29, 33.52, 29.79, 27.97, 27.85, 27.39, 27.13, 25.27, 20.76, 19.25, 18.25, 16.02, 15.90, $15.32,14.69$. MS: $\mathrm{m} / \mathrm{z} 480.35\left(\mathrm{M}^{+}\right)$; Anal. Calcd. for $\mathrm{C}_{33} \mathrm{H}_{52} \mathrm{O}_{2}: \mathrm{C}, 82.44 ; \mathrm{H}, 10.90$. Found: $\mathrm{C}, 82.61 ; \mathrm{H}, 10.99$.

3ß,28-Dibenzoyloxy-30-oxo-30-(2-oxopropyl)lup-20(29)-ene (14). A solution of 10 (1.4 mmol) and $\mathrm{CH}_{3} \mathrm{COONa}$ $(0.7 \mathrm{mmol})$ in acetone $(100 \mathrm{ml})$ was cooled to $0-5{ }^{\circ} \mathrm{C}$, then the Jones reagent $(0.8 \mathrm{ml})$ was added slowly, with subsequent stirring of the reaction mixture for $15 \mathrm{~min}$. The progress of the reaction was monitored by TLC. The reaction mixture was extracted with ethyl acetate, washed with $\mathrm{H}_{2} \mathrm{O}(5 \times 10 \mathrm{ml})$, and dried over anhydrous $\mathrm{MgSO}_{4}$. The solvent was evaporated, and the residue was subjected to CC (eluent: light petroleum-ethyl 
acetate, 10:1). Yield: $30 \%$, m.p. $142.1^{\circ} \mathrm{C},[\alpha]_{D}^{21}+18.4$ (c 0.6, $\left.\mathrm{CHCl}_{3}\right)$. IR (cm $\left.{ }^{-1}\right): 1716 .{ }^{1} \mathrm{H} \mathrm{NMR}(400 \mathrm{MHz} \mathrm{CDCl} 3)$ : $\delta_{\mathrm{H}} 15.67(1 \mathrm{H}, \mathrm{br} \mathrm{s}, \mathrm{OH}), 8.05-8.00(4 \mathrm{H}, \mathrm{m}, \mathrm{Ph}), 7.55-7.49(2 \mathrm{H}, \mathrm{m}, \mathrm{Ph}), 7.44-7.38(4 \mathrm{H}, \mathrm{m}, \mathrm{Ph}), 5.87(1 \mathrm{H}, \mathrm{s}, 31-\mathrm{H})$, 5.79 and $5.47\left(2 \mathrm{H}, 2 \mathrm{~s}, 29-\mathrm{H}_{2}\right), 4.69(1 \mathrm{H}, \mathrm{dd}, J 5.1,11.0 \mathrm{~Hz}, 3-\mathrm{H}), 4.53$ and $4.13\left(2 \mathrm{H}, 2 \mathrm{~d}, J 11.1 \mathrm{~Hz}, 28-\mathrm{H}_{2}\right), 2.73$ $(1 \mathrm{H}, \mathrm{td}, J 11.2,5.4 \mathrm{~Hz}, 19-\mathrm{H}), 2.11\left(3 \mathrm{H}, \mathrm{s}, 33-\mathrm{H}_{3}\right), 1.07,0.99,0.98,0.90,0.87\left(15 \mathrm{H}, 5 \mathrm{~s}, 5 \mathrm{CH}_{3}\right) .{ }^{13} \mathrm{C} \mathrm{NMR}(100$ $\left.\mathrm{MHz}, \mathrm{CDCl}_{3}\right): \delta_{\mathrm{C}} 193.13,185.30,166.86,166.22,151.62,132.86,132.62,131.00,130.42,129.53(2 \mathrm{C}), 129.47$ (2C), 128.35 (2C), 128.25 (2C), 118.64, 97.22, 81.51, 63.17, 55.46, 51.45, 50.21, 46.76, 42.71, 40.95, 40.92, 38.42 , 38.17, 37.45, 37.11, 34.55, 34.18, 33.04, 30.11, 28.08 (2C), 27.58, 27.15, 25.73, 23.71, 21.01, 18.16, 16.73, 16.07, 14.75. Anal. Calcd. for $\mathrm{C}_{47} \mathrm{H}_{60} \mathrm{O}_{6}$ : C, 78.30; $\mathrm{H}, 8.39$. Found: $\mathrm{C}, 78.13 ; \mathrm{H}, 8.54$.

3ß,28-Diacetoxy-30-oxo-30-(2-oxopropyl)lup-20(29)-ene (15). A solution of 11 (1.7 mmol) and $\mathrm{CH}_{3} \mathrm{COONa}_{(0.8}$ $\mathrm{mmol})$ in acetone $(100 \mathrm{ml})$ was cooled to $0-5{ }^{\circ} \mathrm{C}$, then the Jones reagent $(1.0 \mathrm{ml})$ was added slowly, with subsequent stirring of the reaction mixture for $15 \mathrm{~min}$. The progress of the reaction was monitored by TLC. The reaction mixture was extracted with ethyl acetate, washed with $\mathrm{H}_{2} \mathrm{O}(5 \times 10 \mathrm{ml})$, and dried over anhydrous $\mathrm{MgSO}_{4}$. The solvent was evaporated, and the residue was subjected to CC (eluent: light petroleum-ethyl acetate, 10:1). Yield: $30 \%$, m.p. $100.3^{\circ} \mathrm{C},[\alpha]_{D}^{21}+2.4\left(c 0.59, \mathrm{CHCl}_{3}\right) \cdot \mathrm{IR}\left(\mathrm{cm}^{-1}\right): 1733 .{ }^{1} \mathrm{H} \mathrm{NMR}\left(400 \mathrm{MHz} \mathrm{CDCl}_{3}\right)$ : $\delta_{\mathrm{H}} 15.65\left(1 \mathrm{H}\right.$, br s, OH), $5.85(1 \mathrm{H}, \mathrm{s}, 31-\mathrm{H}), 5.77$ and $5.44\left(2 \mathrm{H}, 2 \mathrm{~s}, 29-\mathrm{H}_{2}\right), 4.45(1 \mathrm{H}, \mathrm{dd}, J 5.7,10.8 \mathrm{~Hz}, 3-\mathrm{H}), 4.27$ and $3.88\left(2 \mathrm{H}, 2 \mathrm{~d}, J 10.8 \mathrm{~Hz}, 28-\mathrm{H}_{2}\right), 2.65(1 \mathrm{H}, \mathrm{td}, J 11.3,5.5 \mathrm{~Hz}, 19-\mathrm{H}), 2.12\left(3 \mathrm{H}, \mathrm{s}, 33-\mathrm{H}_{3}\right), 2.06$ and $2.02(6 \mathrm{H}, 2 \mathrm{~s}$, $\left.2 \mathrm{CH}_{3} \mathrm{COO}-\right), 1.03,0.95,0.82,\left(9 \mathrm{H}, 3 \mathrm{c}, 3 \mathrm{CH}_{3}\right), 0.83\left(6 \mathrm{H}, \mathrm{s}, 2 \mathrm{CH}_{3}\right) .{ }^{13} \mathrm{C} \mathrm{NMR}\left(100 \mathrm{MHz}, \mathrm{CDCl}_{3}\right): \delta_{\mathrm{C}} 193.17,185.34$, 171.50, 170.94, 151.68, 118.64, 97.24, 80.91, 62.66, 55.42, 51.46, 50.22, 46.40, 42.66, 40.93, 38.44, 37.81, $37.38,37.09,34.39,34.21,33.01,29.88,27.94$ (2C), 27.57, 27.08, 25.77, 23.68, 21.24, 21.01, 20.97, 18.17, 16.46, 16.11, 16.05, 14.70. Anal. Calcd. for $\mathrm{C}_{37} \mathrm{H}_{56} \mathrm{O}_{6}: \mathrm{C}, 74.46 ; \mathrm{H}, 9.46$. Found: $\mathrm{C}, 74.73 ; \mathrm{H}, 9.12$.

2-(1,3-Dioxobut-1-yl)-19ß,28-epoxyolean-1(2)-en-3-one (16). A solution of 12 (1.4 mmol) and $\mathrm{CH}_{3} \mathrm{COONa}$ $(0.95 \mathrm{mmol})$ in acetone $(100 \mathrm{ml})$ was cooled to $0-5{ }^{\circ} \mathrm{C}$, then the Jones reagent $(1.0 \mathrm{ml})$ was added slowly, with subsequent stirring of the reaction mixture for $15 \mathrm{~min}$. The progress of the reaction was monitored by TLC. The reaction mixture was extracted with ethylacetate, washed with $\mathrm{H}_{2} \mathrm{O}(5 \times 10 \mathrm{ml})$, and dried over anhydrous $\mathrm{MgSO}_{4}$. The solvent was evaporated, and the residue was subjected to $\mathrm{CC}$ (eluent: light petroleum-ethylacetate, $10: 1)$. Yield: $40 \%$, m.p. $114.4^{\circ} \mathrm{C}$. $[\alpha]_{D}^{21}+2.7$ (c 0.6). IR $\left(\mathrm{cm}^{-1}\right)$ : 1684,1615 . For form A. ${ }^{1} \mathrm{H}$ NMR $\left(400 \mathrm{MHz}, \mathrm{CDCl}_{3}\right): \delta_{\mathrm{H}} 15.70(1 \mathrm{H}, \mathrm{br} \mathrm{s}, \mathrm{OH}), 7.92(1 \mathrm{H}, \mathrm{s}, 1-\mathrm{H}), 6.20(1 \mathrm{H}, \mathrm{s}, 32-\mathrm{H}), 3.78$ and $3.45(2 \mathrm{H}, 2 \mathrm{~d}, \mathrm{~J}$ $\left.7.8 \mathrm{~Hz}, 28-\mathrm{H}_{2}\right), 3.54(1 \mathrm{H}, \mathrm{s}, 19-\mathrm{H}), 2.13\left(3 \mathrm{H}, \mathrm{s}, 34-\mathrm{H}_{3}\right), 1.16,1.09,1.05,1.02,0.80\left(15 \mathrm{H}, 5 \mathrm{~s}, 5 \mathrm{CH}_{3}\right), 0.92(6 \mathrm{H}, \mathrm{s}$, $\left.2 \mathrm{CH}_{3}\right) .{ }^{13} \mathrm{C}$ NMR $\left(100 \mathrm{MHz}, \mathrm{CDCl}_{3}\right): \delta_{\mathrm{C}} 202.97,196.88,176.62,163.63,131.17,100.35,87.88,71.25,52.21$, $46.73,46.00,44.81,41.58,41.48,41.04,39.56,36.73,36.27,34.51,32.92,32.71,28.77,28.67,26.58,26.41$, 26.28, 26.23, 24.52, 21.86, 21.07, 19.51, 18.83, 16.15, 13.29. Anal. Calcd. for $\mathrm{C}_{34} \mathrm{H}_{50} \mathrm{O}_{4}: \mathrm{C}, 78.12 ; \mathrm{H}, 9.64$. Found: $\mathrm{C}, 78.22 ; \mathrm{H}, 9.85$.

3ß-Hydroxy-28-(2,4-dioxobutylidene)lup-20(29)-ene (17). $t$-BuOK (4 mmol) was added to a solution of 13 (2 mmol) and $\mathrm{HCOOC}_{2} \mathrm{H}_{5}(6 \mathrm{mmol})$ in $t-\mathrm{BuOH}(50 \mathrm{ml})$. The reaction mixture stirred for $4 \mathrm{~h}$ at $\mathrm{rt}$. With $10 \% \mathrm{HCl}$ added, the reaction mixture was extracted with ethyl acetate. The organic layer was separated, washed with $\mathrm{H}_{2} \mathrm{O}(2 \times 10 \mathrm{ml})$, and dried over anhydrous $\mathrm{MgSO}_{4}$. The solvent was evaporated, and the residue was subjected to CC (eluent: light petroleum-ethyl acetate, 5:1). Yield: $65 \%$, m.p. $153.0{ }^{\circ} \mathrm{C},[\alpha]_{D}^{21}-25.5\left(\mathrm{c} 1.0, \mathrm{CHCl}_{3}\right) . \mathrm{IR}\left(\mathrm{cm}^{-1}\right)$ : 3447, 1717, 1642, 1613. ${ }^{1} \mathrm{H}$ NMR $\left(400 \mathrm{MHz} \mathrm{CDCl}_{3}\right): \delta_{\mathrm{H}} 8.46$ and $5.57(2 \mathrm{H}, 2 \mathrm{~d}, \mathrm{~J} 3.5 \mathrm{~Hz}, 33-\mathrm{H}, 34-\mathrm{H}), 7.19$ and $5.97(2 \mathrm{H}, 2 \mathrm{~d}, J 16.1 \mathrm{~Hz}, 28-\mathrm{H}, 31-\mathrm{H}), 4.71$ and $4.60\left(2 \mathrm{H}, 2 \mathrm{~s}, 29-\mathrm{H}_{2}\right), 3.16(1 \mathrm{H}, \mathrm{dd}, J 5.0,11.2 \mathrm{~Hz}, 3-\mathrm{H}), 2.47(1 \mathrm{H}$, $\mathrm{td}, J 11.2,5.4 \mathrm{~Hz}, 19-\mathrm{H}), 1.68\left(3 \mathrm{H}, \mathrm{s}, 30-\mathrm{H}_{3}\right), 0.97,0.95,0.94,0.80,0.74\left(15 \mathrm{H}, 5 \mathrm{~s}, 5 \mathrm{CH}_{3}\right) .{ }^{13} \mathrm{C} \mathrm{NMR}(100 \mathrm{MHz}$, $\left.\mathrm{CDCl}_{3}\right): \delta_{\mathrm{C}} 182.99,182.59,150.84,149.69,125.25,110.05,101.17,78.97,55.35,50.42,50.28,49.91,47.80$, $42.82,40.84,38.96,38.85,38.79,38.73,37.19,34.34,33.54,29.82,27.98,27.89,27.40,25.29,20.77,19.27$, 18.27, 16.03, 15.99, 15.33, 14.69. Anal. Calcd. for $\mathrm{C}_{34} \mathrm{H}_{52} \mathrm{O}_{3}: \mathrm{C}, 80.26 ; \mathrm{H}, 10.30$. Found: $\mathrm{C}, 80.41 ; \mathrm{H}, 10.55$. 
3ß,28-Dibenzoyloxy-20-(3'-methyl-1H-pyrazol-5'-yl)-30-norlup-20(29)-ene (18). Compound 14 (0.14 mmol) was dissolved in $2 \mathrm{~mL}$ of ethanol, and hydrazine hydrate $(0.17 \mathrm{mmol})$ was added. Then, $2 \mathrm{ml}$ of $\mathrm{CH}_{3} \mathrm{COOH}$ were added under stirring. The mixture was refluxed and monitored by TLC until the starting material completely disappeared (1.5 h). The product was extracted with ethyl acetate. The organic layer was separated, washed with $\mathrm{H}_{2} \mathrm{O}$, and dried over anhydrous $\mathrm{MgSO}_{4}$. The solvent was evaporated, and the residue was subjected to CC (eluent: light petroleum-ethyl acetate, 5:1). Yield: $85 \%$, m.p. $129.0^{\circ} \mathrm{C},[\alpha]_{D}^{21}+16.0\left(\mathrm{c} 0.5, \mathrm{CHCl}_{3}\right) \cdot \mathrm{IR}\left(\mathrm{cm}^{-1}\right)$ : 3324, 3206, 1717. ${ }^{1} \mathrm{H}$ NMR $\left(400 \mathrm{MHz}, \mathrm{CDCl}_{3}\right): \delta_{\mathrm{H}} 8.20(1 \mathrm{H}, \mathrm{br} \mathrm{s}, \mathrm{NH}), 8.05-7.99(4 \mathrm{H}, \mathrm{m}, \mathrm{Ph}), 7.55-7.49(2 \mathrm{H}, \mathrm{m}$, $\mathrm{Ph}), 7.43-7.37(4 \mathrm{H}, \mathrm{m}, \mathrm{Ph}), 6.12\left(1 \mathrm{H}, \mathrm{s}, 4^{\prime}-\mathrm{H}\right), 5.39$ and $5.11\left(2 \mathrm{H}, 2 \mathrm{~s}, 29-\mathrm{H}_{2}\right), 4.69(1 \mathrm{H}, \mathrm{dd}, J 5.1,11.0 \mathrm{~Hz}, 3-\mathrm{H})$, 4.58 and $4.15\left(2 \mathrm{H}, 2 \mathrm{~d}, J 11.1 \mathrm{~Hz}, 28-\mathrm{H}_{2}\right), 2.88(1 \mathrm{H}, \mathrm{td}, J 11.2,5.5 \mathrm{~Hz}, 19-\mathrm{H}), 2.28\left(3 \mathrm{H}, \mathrm{s}, 6^{\prime}-\mathrm{H}_{3}\right), 1.06,0.98,0.97$, $0.89,0.86\left(15 \mathrm{H}, 5 \mathrm{c}, 5 \mathrm{CH}_{3}\right) .{ }^{13} \mathrm{C} \mathrm{NMR}\left(100 \mathrm{MHz}, \mathrm{CDCl}_{3}\right): \delta_{\mathrm{C}} 166.86,166.23,149.63,145.74,143.99,132.81$, 132.60, 131.02, 130.51, 129.54 (2C), 129.47 (2C), 128.33 (2C), 128.24 (2C), 109.71, 102.62, 81.55, 63.25, $55.45,50.55,50.24,46.80,42.74,40.95,38.39,38.18,37.57,37.10,34.54,34.18,32.56,30.10,29.63,28.09$, $27.20,27.06,23.72,20.97,18.17,16.73,16.10,16.08,14.81,12.07$. Anal. Calcd. for $\mathrm{C}_{47} \mathrm{H}_{60} \mathrm{~N}_{2} \mathrm{O}_{4}: \mathrm{C}, 78.73 ; \mathrm{H}$, 8.43; N, 3.91. Found: C, 78.67; H, 8.58; N, 3.88.

19ß,28-Epoxy-2-(3'-methyl-1H-pyrazol-5'-yl)-18 $\alpha$ H-olean-1(2)en-3-one (19). Compound 16 (0.2 mmol) was dissolved in $1 \mathrm{~mL}$ of ethanol with subsequent addition of hydrazine hydrate $(0.22 \mathrm{mmol})$. Then, $1 \mathrm{ml}$ of $\mathrm{CH}_{3} \mathrm{COOH}$ was added under stirring. The mixture was refluxed and monitored by TLC until the starting material completely disappeared $(1.5 \mathrm{~h})$. The product was extracted with ethyl acetate. The organic layer was separated, washed with $\mathrm{H}_{2} \mathrm{O}$, and dried over anhydrous $\mathrm{MgSO}_{4}$. The solvent was evaporated, and the residue was subjected to $\mathrm{CC}$ (eluent: light petroleum-ethyl acetate, 7:3). Yield: $83 \%$, m.p. $139.5{ }^{\circ} \mathrm{C} .[\alpha]_{D}^{21}+42.4(c 0.5$, $\mathrm{CHCl}_{3}$ ). IR (solution in $\mathrm{CHCl}_{3}, \mathrm{~cm}^{-1}$ ): 3427, 3206, 1672. $\left.{ }^{1} \mathrm{H} \mathrm{NMR}\left(400 \mathrm{MHz}^{\mathrm{CDCl}}\right)_{3}\right): \delta_{\mathrm{H}} 8.22(1 \mathrm{H}, \mathrm{br} \mathrm{s}, \mathrm{NH}), 7.51$ $(1 \mathrm{H}, \mathrm{s}, 1-\mathrm{H}), 6.23\left(1 \mathrm{H}, \mathrm{s}, 4^{\prime}-\mathrm{H}\right), 3.78$ and $3.45\left(2 \mathrm{H}, 2 \mathrm{~d}, J 7.9 \mathrm{~Hz}, 28-\mathrm{H}_{2}\right), 3.54(1 \mathrm{H}, \mathrm{s}, 19-\mathrm{H}), 2.28\left(3 \mathrm{H}, \mathrm{s}, 6^{\prime}-\mathrm{H}_{3}\right)$, 1.17, 1.14, 1.10, 1.06, $0.80\left(15 \mathrm{H}, 5 \mathrm{~s}, 5 \mathrm{CH}_{3}\right), 0.94\left(6 \mathrm{H}, \mathrm{s}, 2 \mathrm{CH}_{3}\right)$. Спектр ${ }^{13} \mathrm{C} \mathrm{NMR}\left(100 \mathrm{MHz}, \mathrm{CDCl}_{3}\right): \delta_{\mathrm{C}} 204.82$, $156.49,147.12,141.25,124.55,102.02,87.87,71.24,52.62,46.75,45.40,45.04,41.62,41.48,41.07,39.34$, $36.73,36.27,34.43,33.15,32.70,28.78,28.66,26.39,26.31,26.24,24.53,21.55,21.50,19.62,19.19,16.21$, 13.33, 12.97. MS: $\mathrm{m} / \mathrm{z} 518.3\left(\mathrm{M}^{+}\right)$; Anal. Calcd. for $\mathrm{C}_{34} \mathrm{H}_{50} \mathrm{~N}_{2} \mathrm{O}_{2}: \mathrm{C}, 78.72 ; \mathrm{H}, 9.71 ; \mathrm{N}, 5.40$. Found: $\mathrm{C}, 78.96 ; \mathrm{H}$, 9.64; N, 5.57.

3ß-Hydroxy-28-[(1H-pyrazol-3'-yl)methylylidene]lup-20(29)-ene (20). Compound 17 (0.58 mmol) was dissolved in $2 \mathrm{~mL}$ of ethanol with subsequent addition of hydrazine hydrate $(0.88 \mathrm{mmol})$. Then, $2 \mathrm{ml}$ of $\mathrm{CH}_{3} \mathrm{COOH}$ were added under stirring. The mixture was refluxed and monitored by TLC until the starting material completely disappeared $(1.5 \mathrm{~h})$. The product was extracted with ethyl acetate. The organic layer was separated, washed with $\mathrm{H}_{2} \mathrm{O}$, and dried over anhydrous $\mathrm{MgSO}_{4}$. The solvent was evaporated, and the residue was subjected to CC (eluent: light petroleum-ethyl acetate, 7:3). Yield: 95\%, m.p. $158.8^{\circ} \mathrm{C},[\alpha]_{D}^{21}-18.8$ (c 0.6 , $\left.\mathrm{CHCl}_{3}\right)$. IR $\left(\mathrm{cm}^{-1}\right): 3209,1718,1642 .{ }^{1} \mathrm{H}$ NMR $\left(400 \mathrm{MHz}, \mathrm{CDCl}_{3}\right): \delta_{\mathrm{H}} 7.49$ and $6.33\left(2 \mathrm{H}, 2 \mathrm{~d}, J 1.7 \mathrm{~Hz}, 4^{\prime}-\mathrm{H}, 5^{\prime}-\mathrm{H}\right)$, 6.48 and $6.44(2 \mathrm{H}, 2 \mathrm{~d}, J 16.6 \mathrm{~Hz}, 28-\mathrm{H}, 31-\mathrm{H}), 5.79(1 \mathrm{H}, \mathrm{s}, \mathrm{NH}), 4.70$ and $4.58\left(2 \mathrm{H}, 2 \mathrm{~s}, 29-\mathrm{H}_{2}\right), 3.17(1 \mathrm{H}, \mathrm{dd}, J 5.1$, $11.0 \mathrm{~Hz}, 3-\mathrm{H}), 2.46(1 \mathrm{H}, \mathrm{td}, J=11.0,4.8 \mathrm{~Hz}, 19-\mathrm{H}), 1.68\left(3 \mathrm{H}, \mathrm{s}, 30-\mathrm{H}_{3}\right), 0.97,0.95,0.94,0.79,0.74(15 \mathrm{H}, 5 \mathrm{c}$, $\left.5 \mathrm{CH}_{3}\right) .{ }^{13} \mathrm{C} N M R\left(100 \mathrm{MHz}, \mathrm{CDCl}_{3}\right): \delta_{\mathrm{C}} 150.24,147.12,136.88,134.18,118.66,109.72,101.88,78.97,55.35$, $50.45,49.78,49.41,47.95,42.82,40.87,38.93,38.85,38.74,38.44,37.19,34.32,34.16,29.98,28.02,27.84$, 27.38, 25.28, 20.85, 19.32, 18.30, 16.05, 16.01, 15.40, 14.74. Anal. Calcd. for $\mathrm{C}_{34} \mathrm{H}_{52} \mathrm{~N}_{2} \mathrm{O}: \mathrm{C}, 80.90 ; \mathrm{H}, 10.38 ; \mathrm{N}$, 5.55. Found: $\mathrm{C}, 81.01 ; \mathrm{H}, 10.22 ; \mathrm{N}, 5.34$.

3ß,28-Dibenzoyloxy-20-(3'-methylisoxazol-5'-yl)-30-norlup-20(29)-ene (21). Compound 14 (0.14 mmol) was dissolved in $4 \mathrm{~mL}$ of ethanol with subsequent addition of hydroxylamine hydrochloride $(0.14 \mathrm{mmol})$ and $\mathrm{CH}_{3} \mathrm{COONa}(0.14 \mathrm{mmol})$. The mixture was refluxed and monitored by TLC until the starting material completely disappeared $(1.5 \mathrm{~h})$. The product was extracted with ethyl acetate. The organic layer was separated, washed 
with $\mathrm{H}_{2} \mathrm{O}$, and dried over anhydrous $\mathrm{MgSO}_{4}$. The solvent was evaporated, and the residue was subjected to $\mathrm{CC}$ (eluent: light petroleum-ethyl acetate, 10:1). Yield: $73 \%$, m.p. $69.0{ }^{\circ} \mathrm{C},[\alpha]_{D}^{21}+12.0\left(\mathrm{c} 0.5, \mathrm{CHCl}_{3}\right) \cdot \mathrm{IR}\left(\mathrm{cm}^{-1}\right)$ : 1716, 1451. ${ }^{1} \mathrm{H}$ NMR $\left(400 \mathrm{MHz}_{\mathrm{CDCl}}\right): \delta_{\mathrm{H}}$ 8.06-8.00 (4H, m, Ph), 7.56-7.49 (2H, m, Ph), 7.44-7.38 (4H, m, Ph), $6.12\left(1 \mathrm{H}, \mathrm{s}, 4^{\prime}-\mathrm{H}\right), 5.41$ and $5.14\left(2 \mathrm{H}, 2 \mathrm{~s}, 29-\mathrm{H}_{2}\right), 4.69(1 \mathrm{H}, \mathrm{dd}, J 5.2,10.9 \mathrm{~Hz}, 3-\mathrm{H}), 4.58$ and $4.16(2 \mathrm{H}, 2 \mathrm{~d}, J 11.1$ $\left.\mathrm{Hz}, 28-\mathrm{H}_{2}\right), 2.87(1 \mathrm{H}, \mathrm{td}, \mathrm{J} 11.2,5.7 \mathrm{~Hz}, 19-\mathrm{H}), 2.30\left(3 \mathrm{H}, \mathrm{s}, 6^{\prime}-\mathrm{H}_{3}\right), 1.07,0.99,0.97,0.90,0.87\left(15 \mathrm{H}, 5 \mathrm{~s}, 5 \mathrm{CH}_{3}\right) .{ }^{13} \mathrm{C}$ NMR $\left(100 \mathrm{MHz}_{1} \mathrm{CDCl}_{3}\right): \delta_{\mathrm{C}} 166.92,166.27,149.17,144.79,144.10,132.87,132.63,131.05,130.50,129.58$ (2C), 129.50 (2C), 128.37 (2C), 128.27 (2C), 106.42, 102.91, 81.59, 63.20, 55.48, 50.67, 50.26, 46.86, 42.78, 41.00, 38.42, 38.21, 37.58, 37.14, 34.53, 34.21, 32.60, 30.10, 28.11 (2C), 27.21 (2C), 23.74, 21.00, 18.20, 16.76, 16.13 (2C), 14.83, 11.97. Anal. Calcd. for $\mathrm{C}_{47} \mathrm{H}_{59} \mathrm{NO}_{5}$ : C, 78.62; $\mathrm{H}, 8.28 ; \mathrm{N}, 1.95$. Found: C, 78.81; $\mathrm{H}, 8.41 ; \mathrm{N}$, 2.11 .

19ß,28-Epoxy-2-(3'-methylisoxazol-5'-yl)-18 $\alpha H$-olean-1(2)en-3-one (22). Compound 16 (0.2 mmol) was dissolved in $2 \mathrm{~mL}$ of ethanol with subsequent addition of hydroxylamine hydrochloride $(0.22 \mathrm{mmol})$ and $\mathrm{CH}_{3} \mathrm{COONa}(0.22 \mathrm{mmol})$. The mixture was refluxed and monitored by TLC until the starting material completely disappeared $(1.5 \mathrm{~h})$. The product was extracted with ethyl acetate. The organic layer was separated, washed with $\mathrm{H}_{2} \mathrm{O}$, and dried over anhydrous $\mathrm{MgSO}_{4}$. The solvent was evaporated, and the residue was subjected to CC (eluent: light petroleum-ethyl acetate, 5:1). Yield: $86 \%$, m.p. $79.8^{\circ} \mathrm{C} .[\alpha]_{D}^{21}+36.7\left(c 0.8, \mathrm{CHCl}_{3}\right) . \mathrm{IR}\left(\mathrm{cm}^{-1}\right): 1681$, 1626, 1453. ${ }^{1} \mathrm{H}$ NMR $\left(400 \mathrm{MHz}, \mathrm{CDCl}_{3}\right): \delta_{\mathrm{H}} 7.85(1 \mathrm{H}, \mathrm{s}, 1-\mathrm{H}), 6.61\left(1 \mathrm{H}, \mathrm{s}, 4^{\prime}-\mathrm{H}\right), 3.80$ and $3.49(2 \mathrm{H}, 2 \mathrm{~d}, J 7.8 \mathrm{~Hz}$, $\left.28-\mathrm{H}_{2}\right), 3.59(1 \mathrm{H}, \mathrm{s}, 19-\mathrm{H}), 2.31\left(3 \mathrm{H}, \mathrm{s}, 6^{\prime}-\mathrm{H}_{3}\right), 1.21,1.17,1.15,1.10,0.97,0.96,0.85\left(21 \mathrm{H}, 7 \mathrm{~s}, 7 \mathrm{CH}_{3}\right) .{ }^{13} \mathrm{C} \mathrm{NMR}$ $\left(100 \mathrm{MHz}, \mathrm{CDCl}_{3}\right): \delta_{\mathrm{C}} 201.56,164.21,160.35,158.48,123.72,104.16,87.87,71.21,52.50,46.70,45.29,44.97$, 41.63, 41.46, 41.04, 39.40, 36.71, 36.25, 34.44, 33.10, 32.70, 29.64, 28.75, 28.55, 26.37, 26.22, 24.52, 21.59, 21.46, 19.35, 19.23, 16.21, 13.29, 11.41. MS: m/z 519.35 (M+'); Anal. Calcd. for $\mathrm{C}_{34} \mathrm{H}_{49} \mathrm{NO}_{3}: \mathrm{C}, 78.57 ; \mathrm{H}, 9.50 ; \mathrm{N}$, 2.69. Found: $C, 78.63 ; \mathrm{H}, 9.39 ; \mathrm{N}, 2.78$.

\section{Acknowledgements}

This research was financially supported by the State Contractual Order Nr. AAAA-A19-119031890083-9. Analytical and spectroscopic studies were performed at the "Research of materials and substances" collective Center of PFRC UB RAS.

\section{Supplementary Material}

Supplementary data related to this article, such as the ${ }^{1} \mathrm{H}$ and ${ }^{13} \mathrm{C}$ NMR spectrums for compounds $13-22$ can be found in the online version of the text.

\section{References}

1. Meunier B. Acc. Chem. Res. 2008, 41, 69. https://doi.org/10.1021/ar7000843

2. Kvasnica, M., Urban, M. Dickinson, N.J., Sarek, J. Nat. Prod. Rep. 2015, 32, 1303. https://doi.org/10.1039/c5np00015g 
3. Zhou, M., Zhang, R.-H., Wang, M., Xu, G.-B., Liao, S.-G. Eur. J. Med. Chem. 2017, 131, 222. http://dx.doi.org/10.1016/j.ejmech.2017.03.005

4. Borkova, L., Hodon, J., Urban, M. Asian J. Org. Chem. 2018, 7, 1542. http://dx.doi.org/10.1002/ajoc.201800163

5. Sousa, C. J. L., Freire, C. S. R., Silvestre, A. J. D., Silva, A. M. S. Molecules. 2019, 24, 355. https://doi.org/10.3390/molecules24020355

6. Kel'in, A. V., Maioli A. Curr. Org. Chem. 2003, 7, 1855. https://doi.org/10.1002/chin.200432286

7. Shokova, E. A., Kim, J. K., Kovalev, V. V. Russ. J. Org. Chem. 2015, 51, 755. https://doi.org/10.1134/S1070428015060019

8. Bondarenko, O. B., Zyk, N. V. Chem. Heterocycl. Compd. 2020, 56, 694. https://doi.org/10.1007/s10593-020-02718-0

9. You, Y.-J., Kim, Y., Nam, N.-H., Ahn, B.-Z. Bioorg. Med. Chem. Lett. 2003, 13, 3137. https://doi.org/10.1016/S0960-894X(03)00724-8

10. Chen, J., Gong, Y., Liu, J., Hua, W., Zhang, L., Sun, H. Chem. Biodiversity 2008, 5, 1304. https://doi.org/10.1002/cbdv.200890117

11. Qiu, W.-W., Shen, Q., Yang, S. F., Wang, B., Zou, H., Li, J.-Y., Li, J., Tang, J. Bioorg. Med. Chem. Lett. 2009, $19,6618$. https://doi.org/10.1016/i.bmcl.2009.10.017

12. Li, H., Zou, H., Gao, L., Liu, T., Yang, F., Li, J., Li, J., Qiu, W.-W., Tang, J. Heterocycles 2012, 85, 1117. https://doi.org/10.3987/COM-12-12445

13. Xu, J., Li, Z., Luo, J., Yang, F., Liu, T., Liu, M., Qiu, W.-W., Tang, J. J. Med. Chem. 2012, 55, 3122. https://dx.doi.org/10.1021/im201540h

14. Urban, M., VIk, M., Dzubak, P., Hajduch, M., Sarek, J. Bioorg. Med. Chem. 2012, 20, 3666. http://dx.doi.org/10.1016/i.bmc.2012.03.066

15. Kang, X., Hu, J., Gao, Z., Ju, Y., Xu, C. Med. Chem. Commun. 2012, 3, 1245. https://doi.org/10.1039/c2md20051a

16. Gao, C., Dai, F.-J., Cui, H.-W., Peng, S.-H., He, Y., Wang, X., Yi, F.-Z., Qiu, W.-W. Chem. Biol. Drug. Des. 2014, 84, 223.

https://doi.org/10.1111/cbdd.12308

17. Zhang, H., Zhu, P., Liu, J., Lin, Y., Yao, H., Jiang, J., Ye, W., Wu, X., Xu, J. Bioorg. Med. Chem. Lett. 2015, 25, 728. http://dx.doi.org/10.1016/i.bmcl.2014.11.058

18. Zhang, H., Li, F., Zhu, P., Liu J., Yao, H., Jiang, J., Ye, W., Wu, X., Xu, J. Chem. Biol. Drug Des. 2015, 86, 424. https://doi.org/10.1111/cbdd.12543

19. Laavola, M., Haavikko, R., Hamalainen, M., Leppanen, T., Nieminen, R., Alakurtti, S., Moreira, V. M., YliKauhaluoma, J., Moilanen, E., J. Nat. Prod. 2016, 79, 274.

https://doi.org/10.1021/acs.jnatprod.5b00709

20. Nazarov, M. A., Tolmacheva I. A., Grishko, V. V. AIP Conference Proceedings. 2020, 2280, 050035. https://doi.org/10.1063/5.0018052

21. Ghosh, P., Mandal, A., Ghosh, J., Pal, C., Nanda, A. K. J. J. Asian Nat. Prod. Res. 2012, 14, 141. http://dx.doi.org/10.1080/10286020.2011.640774

22. Nazarov, M. A., Zhikina, L. A., Tolmacheva I. A., Grishko, V. V. Bashkir Chem. J. 2017, $24,28$. 
23. Nazarov, M. A., Tolmacheva, I. A., Eroshenko, D. V., Mayorova, O. A., Dmitriev, M. V., Grishko, V. V. Chem. Heterocycl. Compd. 2020, 56, 1321. https://doi.org/10.1007/s10593-020-02817-y

24. Glushkov, V. A., Shemyakina, D. A., Zhukova, N. K., Pavlogradskaya, L. V., Dmitriev, M. V., Eroshenko, D. V., Galeev, A. R., Mokrushin, I. G. Russ. J. Org. Chem. 2019, 55, 1690. https://doi:10.1134/s1070428019110083

25. Komissarova, N. G., Belenkova, N. G., Spirikhin, L. V., Shitikova, O. V., Yunusov, M. S. Chem. Nat. Compd. 2002, 38, 58.

https://doi.org/10.1023/A:1015733832373 